\title{
FLOWERING OF SIBERIAN PEASHRUB (Caragana arborescens Lam.) AND ITS FORAGE VALUE TO POLLINATING INSECTS
}

\author{
Ernest Stawiarz, Anna Wróblewska \\ Department of Botany, University of Life Sciences in Lublin, Akademicka 15, 20-950 Lublin \\ e-mail: ernest.stawiarz@up.lublin.pl
}

Received: 25.03 .2014

\begin{abstract}
Under the conditions of Lublin (central-eastern Poland), observations were conducted on the flowering of Caragana arborescens shrubs for two growth seasons as well as nectar and pollen production by the flowers of this species was investigated.

The flowering period of Caragana arborescens began at the turn of April and May and lasted for 24 days, while for a single flower it was $6.30 \pm 0.79$ days. The average weight of nectar, sugars and pollen produced by 10 Siberian peashrub flowers was, respectively: $46.70 \pm 8.39 \mathrm{mg}, 22.79 \pm 6.10 \mathrm{mg}$, and $4.45 \pm 0.34 \mathrm{mg}$. The nectar sugar concentration amounted $49.60 \pm 10.08 \%$. Pollen grains reached average dimensions of $21.94 \pm 0.76 \mu \mathrm{m} \times 21.52 \pm 0.71 \mu \mathrm{m}$. During a growing season, one Caragana arborescens shrub can provide on average $101.8 \mathrm{~g}$ of nectar, $49.7 \mathrm{~g}$ of sugars, and $9.7 \mathrm{~g}$ of pollen.
\end{abstract}

Key words: Caragana, flowers, nectar, pollen, insect visits.

\section{INTRODUCTION}

The Siberian peashrub (Caragana arborescens Lam., f. Fabaceae) is a wide-spreading shrub growing to a height of 2-7 meters. Its natural range includes eastern Europe and Asia [1,2]. In some countries (USA, Canada), this species is considered to be invasive $[3,4]$. In Poland Siberian peashrub is grown as an ornamental plant in hedge plantings as well as in urban green spaces and home gardens.

The flowers of the above-mentioned taxon are very frequently visited by pollinating insects, particularly bumblebees and honey bees [5-7]. In few papers Caragana arborescens is indicated as a species that can be utilized as a forage plant in beekeeping. Its insect-pollinated flowers provide both nectar and pollen rewards to bees [8-13]. Nectar is a major carbohydrate food, while floral pollen is a source of protein. Their abundance determines the proper growth of bee colonies.
The aim of the present study was to determine the timing and abundance of flowering of Caragana arborescens Lam. shrubs in urban green spaces of Lublin, to estimate the weight of nectar sugar and pollen produced by its flowers and to determine the morphological characters of pollen grains.

\section{MATERIALS AND METHODS}

\section{Flowering observations}

The flowering biology of Caragana arborescens Lam. was studied during the 2010 and 2011 growth seasons on more than a dozen untrained shrubs in urban green spaces of Lublin. Observations of the bloom dynamics of this species started when the first flowers appeared on the shrubs and continued until the last flowers faded. The following flowering stages of the shrubs were recorded: beginning of flowering first flowers open; full flowering - 50-75\% of flowers in bloom; end of flowering - about $100 \%$ of flowers faded [14].

The life span of a single flower was traced from the bud stage until petal fall using the phenological signs of K r o t o s k a [15]. The following stages were distinguished: loose bud $(\Lambda)$, beginning of flowering $(\mathrm{P})$, full flowering $(\mathrm{O})$, end of flowering $(\mathrm{C})$, and fruit set $(+)$.

The flowering abundance of this species was evaluated on ten untrained shrubs. On each of them, the number of flowers produced per meter of shoot length was extrapolated for a whole plant.

\section{Investigation of nectar and sugar production}

Nectar production in this species was investigated using the pipette method of J a błońs ki [16]. 
Nectar from the flowers was collected when the shrubs were in full bloom. The rate of nectar production was estimated in 10 replicates for each year of the study, collecting in individual pipettes the nectar from 10 flowers. The percentage sugar content in the nectar was determined using an Abbe refractometer. The obtained sugar weight per 10 flowers and the results concerning flowering abundance formed the basis for calculating sugar production per shrub.

\section{Determination of pollen production and morphological characters of pollen grains}

Pollen production in this species was investigated using Warakomska's modified method involving ether extraction and weight measurement [17]. In both growing seasons, mature stamen heads, just before anther dehiscence, were randomly sampled from the flowers at the loose bud stage. Anthers from 10 flowers (100 anthers) were placed on watch glasses in 6 replicates. Having been dried, the pollen was washed out with $70 \%$ ethanol and then with diethyl ether several times. Using the average pollen weight per 10 flowers we calculated pollen production per shrub.

The pollen was used to prepare permanent glycerol-gelatin coated microscope slides in duplicate for each year of the study. Measurements of pollen grains (the length of their polar and equatorial axes) were made using a NIKON ECLIPSE E 600 light microscope at a magnification of $40 \times 15$. Fifty pollen grains were measured on each slide.

The obtained results were statistically analyzed using Statistica 6.0. The differences between means were examined for significance using t-Student test at significance level of $\alpha=0.05$.

\section{RESULTS}

\section{Flowering biology}

Throughout the study period, the Caragana arborescens shrubs (Fig. 1 A) started to bloom in the last days of April or in the first days of May and ended flowering after 23-25 days. The average flowering duration of this taxon was 24 days (Tab. 2). During the full bloom period, which was recorded in the second 10-day period of May, there were from $50 \%$ to $75 \%$ of open flowers on the observed shrubs.

The flowers of Siberian peashrub, similarly to other representatives of the Fabaceae family, are bisexual and characterized by zygomorphic symmetry (Fig. 1 B-D). The five-segmented perianth consists of fused sepals and yellow colored petals which form a raised banner, two lateral wings and two lower petals fused into a keel, inside which the generative parts of the flower are located. The diadelphous androecium is composed of 9 stamens fused by the filaments forming a tube and one entirely free stamen. The nectary is located at its base. The petals are tightly clamped together and as a result of that the flowers are difficult to reach for insects visiting them. Caragana arborescens flowers are borne on short shoots singly or in scanty inflorescences composed of 2 to 5 flowers (Fig. 1 B). From 83 to 165 flowers (on average 111.4) were recorded per meter of shoot length. During a growing season, one shrub produced from 16710 to 28407 flowers (on average 21797.3).

The flower life span lasts, depending on weather conditions, from 5 to 8 days (on average 6.3) (Tab. 2, Fig. 2). In the first year of the study, this period was on average 6.8 days, while in the second year it was shorter by one day (Tab. 2).

\section{Nectar and sugar production}

Nectar secretion in Caragana arborescens started at an early stage of flower development, simultaneously to the beginning of flowering. The average nectar weight per 10 flowers had similar values in both years of the study. They were respectively $45.60 \mathrm{mg}$ in 2010 and $47.80 \mathrm{mg}$ in 2011 (Tab. 3). The nectar was characterized by varying sugar concentration. In the first year, the lower mean air temperature and higher rainfall during the flowering of the shrubs had a direct effect on a lower sugar concentration in the nectar (from $36.0 \%$ to $47.0 \%$, on average $40.1 \%$ ) (Tabs 1 , 3 ). In 2011, under more favorable weather conditions compared to the first year of the study, the nectar sugar content was by far higher (from $56.5 \%$ to $61.5 \%$, on average reaching 59.1\%) (Tabs 1,3). The sugar weight per 10 flowers in the studied species reached on average $18.27 \mathrm{mg}$ in the first year of the study and 27.31 $\mathrm{mg}$ in the second year (the mean for the study period was $22.79 \mathrm{mg}$ ) (Tab. 3).

\section{Pollen production and morphological characters of pollen grains}

Anther dehiscence and pollen release started when the petals opened. Released pollen grains accumulated inside the keel. The average weight of pollen produced by 10 flowers was $4.44 \mathrm{mg}$ and $4.46 \mathrm{mg}$ (the study average was $4.45 \mathrm{mg}$ ) (Tab. 4).

The pollen grains of Caragana arborescens are tricolporate, roundish, with an almost smooth surface of the exine (Fig. 3). For the study period, their average dimensions were as follows: the polar axis 21.94 $\mu \mathrm{m}$ and the equatorial axis $21.52 \mu \mathrm{m}$. The $\mathrm{P} / \mathrm{E}$ ratio was 1.02 (Tab. 4).

Pollen rewards offered by a shrub are strictly dependent on its age as well as on the training method and as a consequence flowering intensity; moreover, they are also dependent on weather conditions during a growing season. One caragana shrub can provide on 
average $101.8 \mathrm{~g}$ of nectar containing $49.7 \mathrm{~g}$ of sugars and $9.7 \mathrm{~g}$ of pollen.

During the flowering period of the shrubs, numerous bee insects were observed on their flowers. These were predominantly honey bees and bumblebees which took advantage of nectar and pollen rewards. Due to hindered access to the nectar, the insects gathered it from the side of the flower, inserting their tongues between the petals and sepals (Fig. 4 A-B). They formed small bright yellow loads from collected pollen. The presence of insects was recorded at different times of the day, with its higher intensity in the afternoon hours.

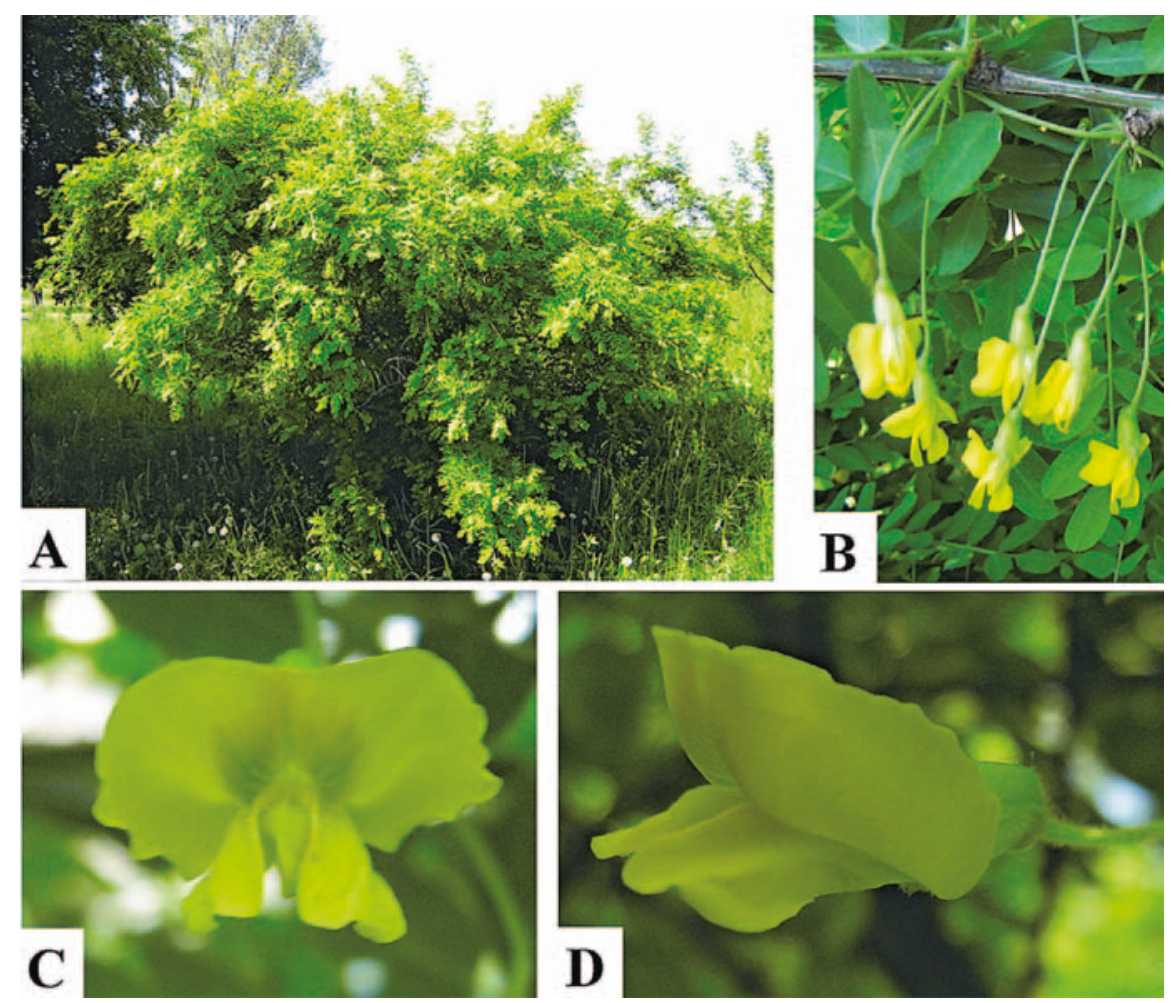

Fig. 1. Caragana arborescens Lam.

A - overall habit of the shrub, B - inflorescences, C, D - flowers

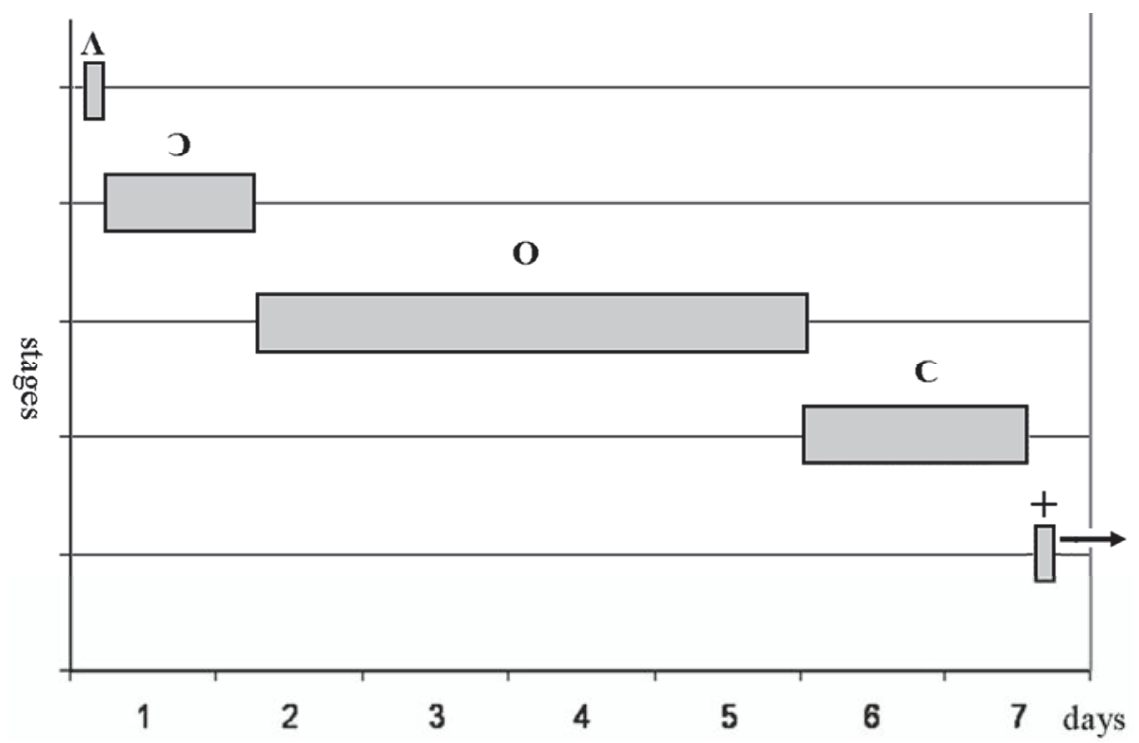

Fig. 2. Successive stages of flower development

(Phenological signs of Krotoska (1958) : $\Lambda$ - loose flower bud, $\mathrm{O}$ - beginning of flowering, $\mathrm{O}$ - full flowering, $\mathrm{C}$ - end of flowering, + - fruit set) 


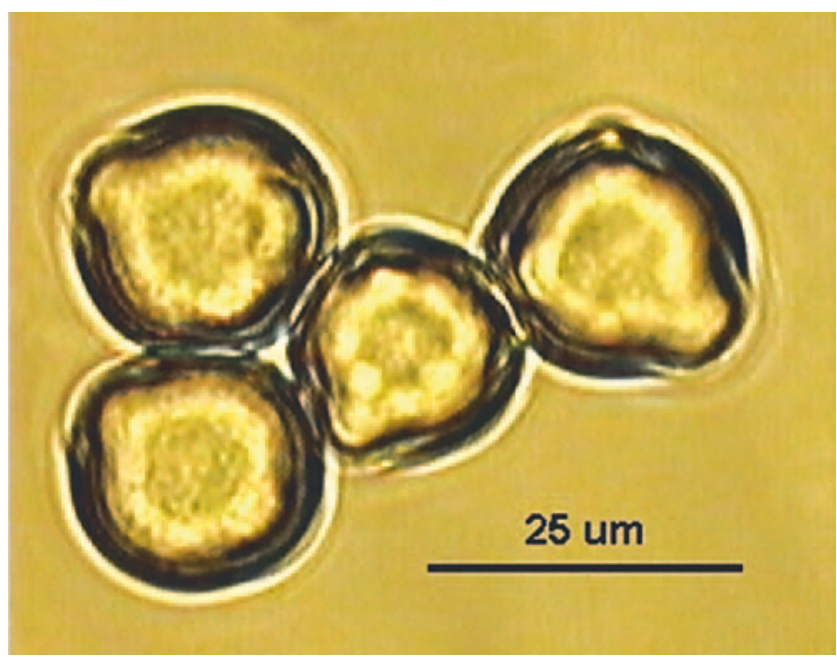

Fig. 3. Pollen grains of Caragana arborescens viewed under a light microscope
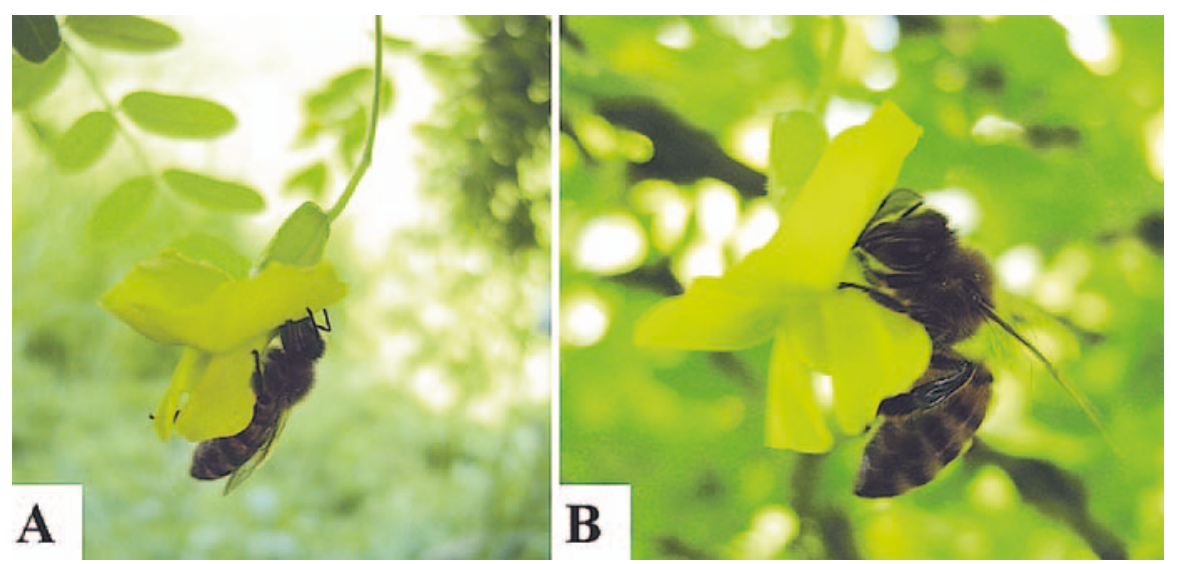

Fig. 4. Honeybees visiting flowers of Caragana arborescens Lam.

Table 1

Mean decade air temperatures and total rainfall during the study period relative to the long-term means

\begin{tabular}{|c|c|c|c|c|c|c|c|c|c|c|}
\hline & \multirow{3}{*}{ Month } & \multicolumn{4}{|c|}{2010} & \multicolumn{4}{|c|}{2011} & \multirow{3}{*}{$\begin{array}{l}\text { long-term } \\
\text { average }\end{array}$} \\
\hline & & \multicolumn{4}{|c|}{ decade } & \multicolumn{4}{|c|}{ decade } & \\
\hline & & I & II & III & mean & I & II & III & mean & \\
\hline \multirow{2}{*}{$\begin{array}{c}\text { Temperature } \\
\left({ }^{\circ} \mathrm{C}\right)\end{array}$} & April & 8.5 & 9.5 & 10.2 & 9.4 & 9.1 & 8.1 & 13.6 & 10.2 & 7.4 \\
\hline & May & 13.6 & 14.5 & 15.2 & 14.5 & 8.8 & 15.8 & 17.9 & 14.3 & 13.0 \\
\hline \multirow{2}{*}{$\begin{array}{l}\text { Precipitation } \\
(\mathrm{mm})\end{array}$} & April & 13.8 & 7.7 & 3.0 & 8.2 & 8.2 & 13.1 & 8.6 & 10.0 & 13.4 \\
\hline & May & 39.7 & 106.7 & 10.3 & 52.2 & 20.4 & 9.8 & 12.0 & 14.1 & 19.2 \\
\hline
\end{tabular}

Table 2

Flowering of Caragana arborescens under the conditions of Lublin

\begin{tabular}{ccccc}
\hline \multirow{2}{*}{ Year } & \multicolumn{2}{c}{ Flowering time } & \multicolumn{2}{c}{ Length of flower live (days) \pm SD } \\
\cline { 2 - 5 } & range & days & range & mean \\
\hline 2010 & $30.04-22.05$ & 23 & $6-8$ & $\mathbf{6 . 8}^{\text {a }} \pm \mathbf{0 . 7 9}$ \\
2011 & $03.05-27.05$ & 25 & $5-6$ & $\mathbf{5 . 8}^{\text {b }} \pm \mathbf{0 . 4 2}$ \\
\hline mean & - & $\mathbf{2 4}$ & - & $\mathbf{6 . 3} \pm \mathbf{0 . 7 9}$ \\
\hline
\end{tabular}


Table 3

Nectar and sugars production

\begin{tabular}{|c|c|c|c|c|c|c|}
\hline \multirow{3}{*}{ Year } & \multicolumn{4}{|c|}{ Mass from 10 flowers (mg) } & \multirow{2}{*}{\multicolumn{2}{|c|}{$\begin{array}{l}\text { Sugar concentration } \\
\text { in the nectar }(\%)\end{array}$}} \\
\hline & \multicolumn{2}{|c|}{ nectar } & \multicolumn{2}{|c|}{ sugars } & & \\
\hline & range & mean $\pm \mathrm{SD}$ & range & mean $\pm \mathrm{SD}$ & range & mean $\pm \mathrm{SD}$ \\
\hline 2010 & $28.0-60.0$ & $45.60^{\mathrm{a}} \pm 9.89$ & $11.5-25.4$ & $18.27^{\mathrm{a}} \pm 4.31$ & $36.0-47.0$ & $40.1^{\mathrm{a}} \pm 3.32$ \\
\hline 2011 & $39.0-60.0$ & $47.80^{\mathrm{a}} \pm 6.94$ & $23.2-34.5$ & $27.31^{\mathrm{b}} \pm 3.81$ & $56.5-61.5$ & $59.1^{\mathrm{b}} \pm 1.78$ \\
\hline mean & & $46.70 \pm 8.39$ & & $22.79 \pm 6.10$ & & $49.6 \pm 10.08$ \\
\hline
\end{tabular}

Table 4

Pollen production and morphological characteristics of the pollen grains of Caragana arborescens

\begin{tabular}{|c|c|c|c|c|c|c|c|}
\hline \multirow{3}{*}{ Year } & \multirow{2}{*}{\multicolumn{2}{|c|}{$\begin{array}{l}\text { Mass of pollen from } 10 \text { flowers } \\
\qquad(\mathrm{mg})\end{array}$}} & \multicolumn{5}{|c|}{ Pollen grains dimensions $(\mu \mathrm{m})$} \\
\hline & & & \multicolumn{2}{|c|}{ Polar axis $(\mathrm{P})$} & \multicolumn{2}{|c|}{ Equatorial axis (E) } & \multirow{2}{*}{$\begin{array}{c}\text { Shape } \\
\text { index } \mathrm{P} / \mathrm{E}\end{array}$} \\
\hline & range & mean $\pm \mathrm{SD}$ & range & mean $\pm \mathrm{SD}$ & range & mean $\pm \mathrm{SD}$ & \\
\hline 2010 & $4.08-4.87$ & $4.44^{\mathrm{a}} \pm 0.34$ & $20.79-23.40$ & $21.98^{\mathrm{a}} \pm 0.53$ & $20.41-23.04$ & $21.52^{\mathrm{a}} \pm 0.69$ & 1.02 \\
\hline 2011 & $4.00-4.89$ & $4.46^{\mathrm{a}} \pm 0.37$ & $20.10-23.54$ & $21.90^{\mathrm{a}} \pm 0.94$ & $20.11-23.01$ & $21.52^{\mathrm{a}} \pm 0.73$ & 1.02 \\
\hline mean & & $4.45 \pm 0.34$ & & $21.94 \pm 0.76$ & & $21.52 \pm 0.71$ & 1.02 \\
\hline
\end{tabular}

\section{DISCUSSION}

The flowering of Caragana arborescens Lam. shrubs in Lublin began at the turn of April and May and lasted on average 24 days. This timing is in agreement with the results of the observations of $\mathrm{De} \mathrm{mi} \mathrm{a} \mathrm{-}$ n o w i c z [18] concerning the studied species, but it is earlier that that reported by $\mathrm{Szklanowska} \mathrm{[8]} \mathrm{as}$ well as by S zk la now sk a and Dą b ska [11]. Under the conditions of the United Kingdom and North America, the bloom period of the study species is later $[5,19,20]$. The flowering of $C$. arborescens occurs in a period of an exceptionally high demand for nectar and pollen of pollinating insects. During this time, there are few trees and shrubs that are an equally attractive source of food for pollinating insects.

The average life span of a single Siberian peashrub flower, which was 6.3 days, is close to that given by some authors for Robinia pseudacacia $[21,22]$ and much shorter than the average life span of a Laburnum anagyroides flower [23]. C. arborescens flowers grow on short shoots singly or in inflorescences composed of 2 to 5 flowers. According to D e m i a nowicz [18] and Szklanowska [8], under the conditions of Lublin an inflorescence of the species in question produces from 2 to 4 flowers, which may have an effect on their lower attractiveness to insects compared to the showy racemes of Robinia pseudacacia or Laburnum anagyroides [21-23].

The average nectar weight per 10 Siberian peashrub flowers was $46.70 \mathrm{mg}$, being lower than that reported for this species by Szklanowska [8]. The average sugar weight per 10 flowers found in this study was comparable to the values described by $\mathrm{Szk}$ la now ska [8] as well as by Szklanow $\mathrm{ska}$ and $\mathrm{Daqbska}$ [11]. A lower sugar weight per 10 flowers was obtained by $\mathrm{Kim}$ [21] as well as by Jabłoński and Kołtowski [22] for Robinia pseudacacia in the conditions of Puławy.

In Europe, honey yield per 1 ha of $C$. arborescens can reach from 15-30 kg to even 50-150 kg [1012,24-27]. G ł uch ov [24], however, stresses that honey yield of this species largely depends on the climatic conditions of a particular region. The honey obtained from caragana nectar is liquid and very bright, and it takes long to crystallize. After crystallization, it is lard-like, almost white, medium-grained, with a pleasant flavor [10,24,28].

The rate of pollen production of $C$. arborescens, as measured by the weight of pollen produced by 10 flowers, ranged from $4.00 \mathrm{mg}$ to $4.89 \mathrm{mg}$, with an average value of $4.45 \mathrm{mg}$. S z k lan ow sk a and $\mathrm{D}$ ąbska [11] show that 10 flowers of the abovementioned species can provide to insects on average $3.64 \mathrm{mg}$ of pollen, which is from $3 \mathrm{~kg}$ to $5 \mathrm{~kg}$ on a per hectare basis. Much higher values of pollen weight per 10 flowers $(6.08 \mathrm{mg})$ were found by $\mathrm{S} \mathrm{ta} \mathrm{w} \mathrm{i} \mathrm{a} \mathrm{r} \mathrm{z}$ and W ró b le w s k a [23] for Laburnum anagyroides.

The tricolporate, with an almost smooth structure of the exine, pollen grains of Caragana arborescens reached average dimensions of $21.94 \mu \mathrm{m} x$ $21.52 \mu \mathrm{m}(\mathrm{P} / \mathrm{E}=1.02)$. A similar description of the morphological characteristics of pollen grains of the analyzed species is given by $\mathrm{Zh}$ a $\mathrm{ng}$ et al. [29], P e r vee $n$ and Q a iser [30] as well as Qiu and Sun [31]. However, Zhang et al. [29] draws attention 
to a rather high variation in the dimensions of pollen grains (the average dimensions were $27.4 \mu \mathrm{m}$ x 20.9 $\mu \mathrm{m}, \mathrm{P} / \mathrm{E}$ 1.31). P e r v e e $\mathrm{n}$ and $\mathrm{Q}$ a i s e r [30] also emphasize that the pollen of Caragana arborescens can reach larger dimensions, ranging $28.55 \mu \mathrm{m} \times 22.50 \mu \mathrm{m}$ $(\mathrm{P} / \mathrm{E}$ 1.27). The above-mentioned authors also note the fine reticulate ornamentation of the exine and, similarly as P olh ill [32], include the pollen of Caragana Lam. in the tribe Galegeae. The dimensions of $C$. arborescens pollen grains found in the present study are smaller than those reported by $\mathrm{Szk}$ a now ska and $\mathrm{D}$ ą b s k a [11]; for this species, they defined only the polar length and its average value was $22.22 \mu \mathrm{m}$. Compared to other shrubs representing the Fabaceae family, Laburnum anagyroides, for which the P/E ratio of pollen grains is 0.98 , is characterized by similar dimensions of pollen grains to those determined for the investigated taxon [23].

The obtained results on nectar and pollen production by the flowers of Caragana arborescens show that this species can be considered to be a valuable bee plant recommended for plantings near apiaries. Its attractiveness to insects is evidenced by the numerous visits of honey bees to its flowers, which gather nectar and pollen from them despite that Siberian peashrub flowers are difficult to access for insects [5]. The fact that bees are interested in gathering nectar from $C$. $a r$ borescens flowers is confirmed by the presence of pollen grains of this species in honeys from, among others, Estonia [13]. Prit s ch [12] reports that insects collect the pollen of this species and form from it small bright yellow loads.

In garden plantings, shrubs of the studied species are often used to form hedges, but after trimming they bloom much less abundantly in comparison with freely growing shrubs. This is closely related to the amount of nectar and pollen rewards offered.

\section{CONCLUSIONS}

1. Under the conditions of Lublin, the flowering period of Caragana arborescens Lam. started at the turn of April and May and lasted on average 3.5 weeks.

2. The amount of nectar and pollen per shrub was strictly dependent on the rate of nectar and pollen production by the flowers as well as on flowering abundance of this species.

3. Caragana arborescens can be a valuable source of early spring nectar and pollen food for Apidae.

\section{Acknowledgements}

The present research was supported by the Ministry of Science and Higher Education of Poland as part of the statutory activities of the Department of Botany, University of Life Sciences in Lublin.

\section{Authors' contribution}

The following declarations about authors' contributions to the research have been made: concept of the study: ES, AW; field research ES; writing of the manuscript: ES, AW; photographs: ES; references: ES, AW.

\section{REFERENCES}

1. Seneta W, Dolatowski J. Dendrologia. Warsaw: Polish Scientific Publishers PWN; 2012.

2. Kozłowski S, Swędrzyński A, Zielewicz W. Rośliny motylkowe w środowisku przyrodniczym. Woda Śr Obsz Wiej. 2011; 11(4): 161-181.

3. Henderson DC, Chapman R. Caragana arborescens invasion in Elk Island National Park, Canada. Nat Areas J. 2006; 26(3): 261-266. http://dx.doi.org/10.3375/0885-8608(2006)26[261:CAIIEI]2.0.CO;2

4. Gederaas L, Moen TL, Skjelseth S, Larsen L K, editors. Alien species in Norway - with the Norwegian Black List 2012. Trondheim: Norwegian Biodiversity Information Centre; 2013.

5. Howes FN. Plants and beekeeping. London: Faber; 1979.

6. Käpylä M, Niemelä P. Flowers visited by honey bee in southern Finland. J Sci Agric Soc Finl. 1979; 51: 17-24.

7. Mount a in MF. Garden plants valuable to bees. London: International Bee Research Association; 1981.

8. Szk la now ska K. Nektarowanie i wydajność miodowa niektórych drzew i krzewów w warunkach Polski. Pszczeln Zesz Nauk. 1978; 22: 117-128.

9. Larsson HC, Shuel R. Nectar trees, shrubs, and herbs of Ontario. Ontario: Ministry of Agriculture and Food; 1990.

10. Bodnarčuk LI, Solomacha TD, Illjaš AM, Solomacha VD, Gorovyj VG. Atlas medonosnych roslyn Ukrainy. Kiev: Urožaj; 1993.

11. Szklanowska K, Dąbska B. Sugars and pollen yield of some trees and shrubs from Fabaceae family. Ann Univ Mariae Curie-Skłodowska Sect EEE Hortic. 1993; 1(13): 103-106.

12. Prits ch G. Bienenweide. Stuttgart: Kosmos; 2007.

13. Puusepp L, Koff T. Pollen analysis of honey from the Baltic region, Estonia. Grana. 2014; 53(1): 54-61. http://dx.doi.org/10.1080/00173134.2013.850532

14. Łukasiewicz A. Potrzeba ujednolicenia metodyki fenologicznej w polskich ogrodach botanicznych i arboretach. Wiad Bot. 1984; 28(2): 153-158.

15. K rotoska T. Pory roku w życiu roślin. Obserwacje fenologiczne w zespołach roślin. Poznań: Polish Scientific Publishers PWN; 1958.

16. Jabłoń ski B. Notes on the method to investigate nectar secretion rate in flowers. J Apic Sci. 2002; 46(2): 117-125. 
17. Wa ra k o m sk a Z . Badania nad wydajnością pyłkową roślin. Pszczeln Zesz Nauk. 1972; 16: 63-90.

18. Demianowicz Z. Rośliny miododajne. Warszawa: Państwowe Wydawnictwo Rolnicze i Leśne; 1953.

19. Gregory KF, Allen ON. Physiological variations and host plant specificities of rhizobia isolated from $\mathrm{Ca}-$ ragana arborescens L. Can J Bot. 1953; 31(6): 730-738. http://dx.doi.org/10.1139/b53-055

20. Dietz DR, Slabaugh PE, Bonner FT. Caragana arborescens Lam.: Siberian peashrub. In: Bonner FT, Karrfalt RP, editors. The woody plant seed manual. Agriculture handbook 727. Washington, DC: US Department of Agriculture, Forest Service; 2008. p. 321-323.

21. K i m T W. Studies on silvicultural properties of Robinia pseudoacacia growing in Korea. In: Proceedings of 31st international beekeeping congress. Warsaw: 1987. p. 1-13.

22. Jabłoński B , Kołtowski Z. Badania wartości pszczelarskiej robinii akacjowej (Robinia pseudacacia L.). Pszczeln Zesz Nauk. 1993; 27: 65-80.

23. Stawiarz E, Wróblewska A. Flowering dynamics and pollen production of Laburnum anagyroides Med. under the conditions of south-eastern Poland. J Apic Sci. 2013; 57(2). http://dx.doi.org/10.2478/jas-2013-0021

24. Głu chov M M. Miedonosnyje rastenija. Moscov: Kołos; 1974.

25. Pom omareva EG. Kormovaja baza pčelovodstva i opylenije selskohozjajstvennych rastenij. Moscov: Kołos; 1973.

26. Ricciardelli D'Albore G, Intoppa F. Flowers and bees. The plants visited by bees and other Apoidea in Europe. Bologna: Calderini Edagricole; 2000.

27. Lipiński M. Pożytki pszczele. Zapylanie i miododajność roślin. Warszawa: Państwowe Wydawnictwo Rolnicze i Leśne; 2010.

28. Yoirish N. Curative properties of honey and bee venom. Hawaii: University Press of the Pacific; 2001.
29. Zhang ML, Tian XY, Ning JC. Pollen morphology and its taxonomic significance of Caragana Fabr. (Fabaceae). Acta Phytotaxon Sin. 1996; 34: 397-409.

30. Perveen A, Q a iser M. Pollen Flora of PakistanVIII Leguminosae (subfamily: Papilionoideae). Turk J Bot. 1998; 22: 73-91.

31. Qiu J, Sun J. A study on pollen morphology of Caragana Farb. and its taxonomic significance. J Shandong Norm Univ Nat Sci. 2003; 18(1): 85-87.

32. Polhill R M. Classification of the Leguminosae. In: Bisby FA, Buckingham J, Harborne JB, editors. Phytochemical dictionary of the Leguminosae. New York, Chapman and Hall; 1994. p. 35-48.

\section{Kwitnienie i wartość pożytkowa karagany syberyjskiej (Caragana arborescens Lam.) dla owadów zapylających}

\section{Streszczenie}

W warunkach Lublina (środkowo-wschodnia Polska) prowadzono przez dwa sezony wegetacyjne obserwacje kwitnienia krzewów Caragana arborescens oraz badania obfitości nektarowania i pylenia jej kwiatów.

Okres kwitnienia gatunku rozpoczynał się na przełomie kwietnia i maja i trwał średnio 24 dni, pojedynczego kwiatu 6,3 dnia. Średnia masa nektaru, cukrów oraz pyłku wytwarzana przez 10 kwiatów karagany syberyjskiej osiągnęła odpowiednio: $46,70 \mathrm{mg}$, 22,79 mg oraz 4,45 mg. Średnia koncentracja cukrów w nektarze wyniosła 49,6\%. Ziarna pyłku osiągały średnie wymiary $21,94 \mu \mathrm{m} \times 21,52 \mu \mathrm{m}$. Jeden krzew Caragana arborescens może dostarczyć w sezonie wegetacyjnym średnio 101,8 g nektaru, 49,7 g cukrów i 9,7 g pyłku.

Handling Editor: Elżbieta Weryszko-Chmielewska

This is an Open Access digital version of the article distributed under the terms of the Creative Commons Attribution 3.0 License (creativecommons.org/licenses/by/3.0/), which permits redistribution, commercial and non-commercial, provided that the article is properly cited.

(C) The Author(s) 2014 Published by Polish Botanical Society 